\title{
Testing of an Improved Maize Roaster for Street Vendors
}

\author{
Deepika Pandey $^{1^{*}}$ and D. Ratna Kumari ${ }^{2}$ \\ ${ }^{1}$ Department of Family Resource Management, GBPUAT, Pantnagar, Uttarakhand, India \\ ${ }^{2}$ Department of Resource Management and Consumer Sciences, \\ PJTSAU, Hyderabad, Telangana, India \\ *Corresponding author
}

\section{A B S T R A C T}

\begin{tabular}{|l|}
\hline Ke y w o r d s \\
Barbecue, \\
Briquettes, \\
Roasting machines \\
\hline Article Info \\
\hline $\begin{array}{l}\text { Accepted: } \\
\text { 10 March } 2020 \\
\text { Available Online: } \\
10 \text { April } 2020\end{array}$ \\
\hline
\end{tabular}

Various roasting machines are developed for miscellaneous roasting purposes for home and industrial purposes. However the development of roasting machines using locally available materials for the local people has not been researched as much. Any innovation was only at the user level. Innovations and adaptations for roasting corn cobs are also seen at the vendor level for whom selling roasted corns is the only source of income for most of them. The process of roasting corns requires continuous fanning of coal to maintain the right amount of heat which is a very stressful process. Various technologies have been created to make the process of roasting easy, quicker and stress-free but most of these were developed outside India. The economic situations of the corn cob roasting vendors have limited the use of automated and power driven equipment to a few large scale processors and vendor. Therefore, to reduce the stress and accidents during roasting and increasing the efficiency, a roasting device with increased efficiency and productivity is needed to be developed. The present study is an attempt to design, develop and test the performance of improved maize roaster (barbecue stove).

\section{Introduction}

Street food vending is a large source of employment in many cities of developing countries (Choudhury et al., 2011). This contributes significantly to households incomes (Feglo and Sakyi, 2012; Biswas et al., 2010; Oladipo, 2010). Many urban dwellers obtain a significant portion of their diet from street foods which increase the street food demand in major cities (Pikuda and Ilelaboye, 2009). The local street vendors selling roasted corns operate seasonally, as per the availability of maize crops.

The corn cobs roasted on hot coals serves as a tasty and nutritious snack. Roasting of corn cobs is done by placing the maize on a glowing charcoal and then turning it occasionally to allow even distribution of 
heat. A hand fan is used by the vendor to blow the air so as to maintain the glowing of charcoal. The rate of heat transfer from the charcoal to the maize depends on how fast the hand fan blows the air current. The process is strenuous as the vendor is tired out with the time before the corn cob is completely roasted. Various indigenous roasting equipments are used by vendors for roasting purposes like tandoor, barbecue, grill, corn roaster etc. The models of stoves used by the local street vendors have capability of cooking two or three corns at a time.

When the number of customers is more, it becomes difficult for the vendor to roast more corns in minimum time. Moreover, the direct contact and exposure of the human body to the heat emitted from the charcoal causes damaging effect on the skin and some organs in the body.

Despite the problems and risks associated with the business, people continue to use this as a source of earning their living (Pearce and Bankole, 1988). In view of the problems identified it was felt that there is a need to develop a corn roasting machine that will be able to roast with higher efficiency and speed, with less stress and accidents. The objective of this study is to design, develop and test the performance of improved barbecue stove for roasting corn cobs.

\section{Methodology}

\section{Research design}

An experimental research design was followed to conduct the study. The experiments were carried out in the AICRP (All India Coordinated Research Project) laboratory of PGRC (Post Graduate Research Centre), Hyderabad and College of Home Science, Saifabad, Hyderabad.

\section{Procedure followed}

The twelve maize vendors were selected randomly for the experiments from the Hyderabad city. To test the performance of the barbecue stove, the experiments were carried out taking briquettes as source of fuel. The time and fuel consumption in barbecue stove was calculated during the process of roasting and the results were compared with conventional stove. Five corns were taken as a standard since the barbecue stove had the provision of cooking five corns at a time.

\section{Details of the stove}

The figure 1 shows the maize roaster (barbecue stove) designed for roasting the corn cobs with features to minimize the stress, probability of accidents and improving the performance of the equipment. The equipment is in cubical shape with insulations to avoid the direct contact of heat to the body and the provisions were made to avoid the contact of fire with the body part (fingers). Instead of making use of hand fan, a blower was attached to the model to reduce the stress produced by constant fanning. The specific materials used in the barbecue stove were:
a. Iron sheet $(6 \mathrm{~mm})$
b. Iron rods ( $2 \mathrm{~mm}$ diameter)
c. Steel nuts and bolts
d. Insulation sheet - asbestos (4.5 mm)

Readily available parts purchased from commercial market and assembled in the barbecue stove were:
a. Hand blower
b. Stand for blower

The details of the parts and fabrication of the stove are as follows:

Blower: It is a mechanical device for creating a current of air used to dry or heat 
something. Instead of using hand fan, the blower was attached to the stove for ensuring supply of air. It helps in minimizing the stress on the wrist and arms caused due to continuous blowing of fan by hands.

Ash tray: A separate tray for collecting the ash made of iron sheets was placed just below the coal tray. It was removable which helped the vendor to remove the ash whenever required.

Coal tray: An iron sheet placed above ash tray for placing the burning coals. The tray is not detachable and is placed securely around the four walls of iron sheet. It prevents the falling of coal outside the stove.

Iron rods: An array of iron rods is placed above the coal tray for placing the corns, avoiding the coals touching the corns. The array was removable which helps in placing of coal on the coal tray before ignition. It makes easy for the vendor to rotate the corns during the roasting process and avoiding the contact of fire and fingers.

Insulations: Asbestos sheets were used as insulation on the four sides to avoid the contact of heat with body. The insulations were provided to prevent the heat loss as well as to avoid the contact of heat with the vendor's body parts.

Iron stand: The stand for making the blower levels the coal tray. The stand was provided to make sure that the blower was at the level from where it provides the air to the right place and in the right direction.

\section{Results and Discussion}

Utilizing briquettes as a fuel, there was no significant difference in the average time consumed for the roasting process in barbecue stove $(24.33 \pm 1.50$ minutes $)$ and conventional stove $(25.83 \pm 1.32$ minutes $)$ Comparing the average time taken to roast five corns, barbecue stove took comparatively less time $(7.33 \pm 0.51$ minutes $)$ than the conventional stove $(9.66 \pm 0.51$ minutes $)$.

Briquettes are eco-friendly fuel which burns for a longer time without emitting smoke and fumes. The results indicated that while using briquettes as a source of fuel, there was no difference in the performance efficiency of the barbecue stove and the conventional stove since there was a minor difference in the total time taken for roasting process. The briquettes took more time for ignition. However, the barbecue stove took less time in roasting the maize cobs with briquettes as the stove has the provision of roasting five corns at a time which saves time and can feed more consumers at a time.

The average briquettes consumption in barbecue stove was observed to $293.33 \pm$ 16.32 grams while in conventional stove, it was observed to be $316.66 \pm 20.65$ grams. There was a significant difference in the quantities of briquettes consumed by the two stoves in roasting process. The figure 2 shows vendors carrying out roasting on barbecue stove.

An organoleptic evaluation done to find out the acceptability of maize cobs when roasted in conventional stove and also in barbecue stove, showed greater overall acceptability when briquettes were used. It suggested that even when briquettes which are eco-friendly, were used there will not be any decrease in their popularity. Hence briquettes as an alternative to charcoal can easily advocate for roasting process. The less quantity of briquettes used in the barbecue model compared to conventional model is an added advantage. 


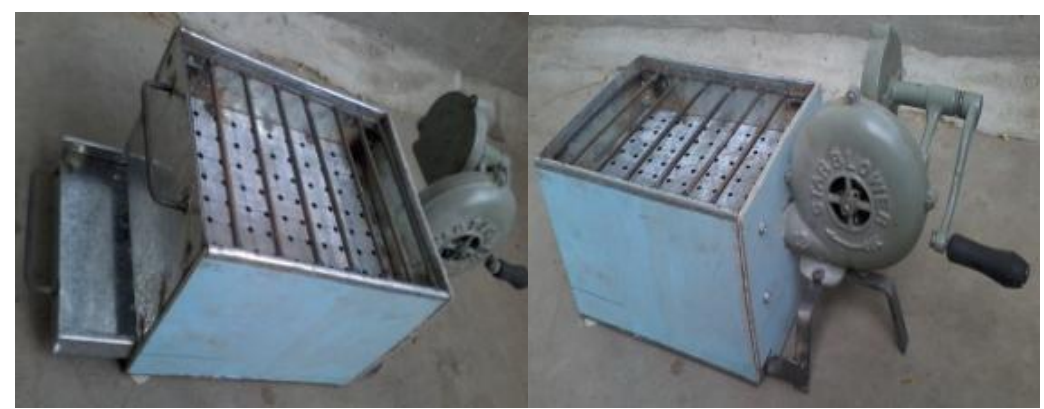

Figure.1 Improved barbecue stove

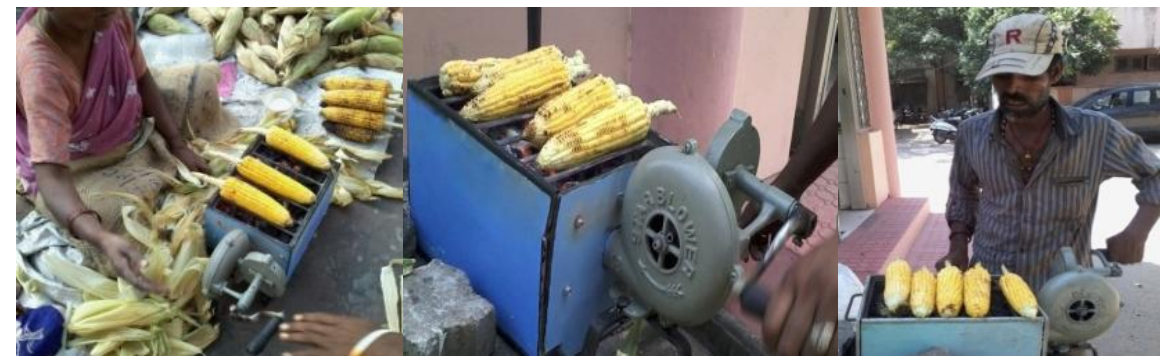

Figure.2 Vendors performing the experiments

Street food has always been a part of Indian urban life but its popularity escalated in the last two decades with more women working outside the home. The food is cheap, easy to find, and, if chosen correctly, healthy. The improved barbecue stove was designed to improve the productivity and reduce the stress faced in the roasting activity. It can accommodate five corns at a time. Moreover the use of blower helped in reducing the stress of fanning.

The separate coal tray and ash tray were provided in the model. Results showed that the barbecue stove was found to be performing more efficiently than the conventional stove using briquettes as a source of fuel. Moreover very less time was consumed in roasting the corn cobs with briquettes in barbecue stove as the stove has the provision of roasting five corns at a time which saves time and can feed more consumers at a time. Briquettes are ecofriendly fuel which burns for a longer time without emitting smoke and fumes. There was less consumption of briquettes in conventional stove as well as in barbecue stove as compared to consumption of charcoal in both the stoves. These experiment results are for only five corn cobs as it was only a laboratory study. However it can be concluded that, once the fuel is ignited it can be used for continuously roasting more corns and thus on an average time consumed for roasting about 50 corn cobs can be reduced much further \pm 5 minutes which may be required for refilling the fuel.

\section{References}

Biswas, S., Parvez, M.A.K., Shafiquzzaman, M., Nahar, S. and Rahman, M.N. (2010). Isolation and Characterization of Escherichia coli in Ready-to-eat Foods Vended in Islamic University, Kushtia. Journal of biology-science. 18: 99-103.

Choudhury, M., Mahanta, L., Goswami, J., Mazumder, M. and Pegoo B. (2011). Socio-economic Profile and Food Safety Knowledge and Practice of Street Food Vendors in the city of Guwahati, Assam, India. Food Control. 22: 196-203. 
Feglo, P. and Sakyi, K. (2012). Bacterial Contamination of Street Vending Food in Kumasi, Ghana. Journal of Medical and Biomedical Sciences. 1(1): $1-8$.

Oladipo, I.C. and Adejumobi, O.D. 2010. Incidence of Antibiotic Resistance in Some Bacterial Pathogens from Street Vended Food in Ogbomoso, Nigeria. Pakistan Journal of Nutrition. 9:10611068.
Pearce, T., Kujore, O.A. and Bankole, V.A. 1988. The Experience of Street Food Vendor in Ile Ife, Nigeria. Generating an Income in the Urban Environment. 58(4): 335-340.

Pikuda, O.O. and Ilelaboye, N.O.A. 2009. Proximate Composition of Street Snacks Purchased from Selected Motor Parks in Lagos. Pakistan Journal of Nutrition. 8: 1657-1660.

\section{How to cite this article:}

Deepika Pandey and Ratna Kumari, D. 2020. Testing of an Improved Maize Roaster for Street Vendors. Int.J.Curr.Microbiol.App.Sci. 9(04): 1040-1044.

doi: https://doi.org/10.20546/ijcmas.2020.904.123 